\title{
FINANCIAL ANALYSIS OF THE AGRICULTURAL HOLDINGS VIABILITY IN ROMANIA IN THE EUROPEAN CONTEXT
}

\author{
Camelia Burja ${ }^{1}$ \\ Vasile Burja ${ }^{2}$
}

\begin{abstract}
The main correlations established between various elements of patrimony highlight the existence and the productive potential dimension of the holding and its capacity to generate economic and financial resources that will ensure its performance and competitiveness. The main objective of the paper is to identify the qualitative differences between the structures of agricultural production in Romania and the European Union and the causes that generate them. The method used to achieve the aimed goal is the comparative analysis of the financial-accounting information existent in the data base of the European Union. The results obtained after applying the methods specific for the financial analysis will serve to characterize the patrimonial situation and the performance of agricultural holdings in Romania and the EU. The relatively modest position of Romanian farms illustrates the precariousness of their viability within the competitive framework of the European agricultural market, resulted in particular from the extremely small size at which agriculture is practiced.
\end{abstract}

Key words: financial analysis, agricultural holdings, patrimony, performance, European agriculture

JEL codes: $M 41,012,013$

\section{Introduction}

The adequate management of accounting information is a desideratum and a tool for better justification of decisions at microeconomic level. In the agricultural sector, the accounting system is an important managerial instrument that may be used to improve the efficiency of agricultural producers and to diminish the environmental impact of specific activities.

In Romania, the accounting regulations in force stipulate that all legal persons who apply the International Financial Reporting Standards (IFRD) must prepare and submit annual financial statements. In agriculture, the content of the annual financial statements reflect the main financial flows resulted from the applied agricultural practices and the obtained performance. In addition to allowing to permanently monitor and control the activities taking place within the agricultural unit, they are also a source of information for various beneficiaries (shareholders, creditors, investors, employees, managers, fiscal bodies, etc.), to whom they provide coherent, relevant, reliable and comparable information, necessary to support economic decisions and to assess the management of agricultural holdings at national level (Feleagă, 2006).

The analysis of agricultural holdings' activity in the European context may use the information provided by Farm Accountancy Data Network (FADN) developed at the level of the European Union. FADN is based on a series of annual studies conducted by member states with the goal to obtain structural and accounting data from the important agricultural manufactures (classified as conducting a trading activity). Afterwards, the data are collected by the specialized services of the European Commission and allow the assessment of the economic situation of agricultural holdings in the EU, as well as the implementation stage of the Common Agricultural Policy. Having a homogeneous character, the accounting information in FADN may serve as a basis

\footnotetext{
${ }^{1}$ University "1 Decembrie 1918” of Alba Iulia, N. Iorga nr.11-13 Street, 510009 Alba Iulia, cameliaburja@yahoo.com

2 University "1 Decembrie 1918” of Alba Iulia, N. Iorga nr.11-13 Street, 510009 Alba Iulia, vasileburja@yahoo.com
} 
for comparison between the agricultural sectors of various EU countries, which facilitates identifying the existent differences and the potential solutions for increasing the economic and environmental efficiency of agricultural producers.

The goal of the paper is to conduct a comparative analysis of the main economic-financial characteristics of farms in Romania and to specify their viability level within the European Union. Financial analysis techniques and accounting data collections from FADN are used to achieve this goal.

\section{Literature review}

Considered one of the major problems of the European Union, monitoring the agricultural sector was a continuous focus for experts in this field. The themes approached lately in literature refer to the implications owed to the reduction of subsidies (Vrolijk et al, 2010), the risk of diminishing agro-biodiversity (Schroder et al., 2007), the investment support for agriculture (Bergschmidt et al., 2009), the performance analysis in the system of sustainable development (Burja et al., 2008), determining the sustainable value of agriculture (Burja et al, 2010), the analysis of employment decisions (Juvancic et al., 2005), the European model of agriculture (Cardwell, 2004), etc.

An important research source for approaching various aspects regarding agricultural activities are the technical, economic and financial parameters supplied by FADN. The data are largely organized in a similar manner to the data in financial accounting and are found in a series of reports, among which the most important are: Balance sheet, Income statement, Financial situation, as well as reports regarding different types of costs - external factors, farming overheads, intermediate consumption, inputs, specific costs (Csajbok, 2009).

In Romania, the accounting information network has been established as an institutional body needed for the accession to the European Union, with the role to supply information about the technical and economic performances of agricultural holdings (Deaconu, 2009).

In the FADN/RICA Regions, Romania is registered with 8 regions: 840 - North-East, 841 South-East, 842 - South-Muntenia, 843 - South-West-Oltenia, 844 - West, 845 - North-West, 846 Center and 847 - Bucharest-Ilfov. The data are available only since 2007, a year that symbols Romania's accession to the European Union. They may be used to detail the comparative analysis of agricultural holdings in terms of territory in order to find opportunities to include agriculture in a much larger and integrated framework of rural development (http://ec.europa.eu/agriculture/rica/pdf/fadnrica eu a3.pdf).

\section{Research methodology}

The research methods used to achieve the goal are specific for the financial analysis. Economic-financial indicators were utilized to diagnose the viability of the agricultural sector, they were determined on the basis of the data gathered for farms in Romania and the European Union at the level of 2007, the most recent year with complete information for all the member states. The information was systemized and organized as a balance sheet due to its importance as a main monitoring instrument of the patrimonial statement of companies. Using rates of patrimonial structure and performance indicators facilitated the identification of aspects characteristic for Romanian agricultural producers and their positioning in relation to the EU's agricultural holdings. The results of the analysis have also enabled the specification of the qualitative differences of the agricultural systems in Romania and of the elements towards which is necessary to shift the restructuring and economic vivification efforts in the following period.

\section{The analysis of the patrimonial potential of Romanian agricultural holdings}

Integrated in the European structures, Romania's agriculture must work in accordance to the mechanisms established by the Common Agricultural Policy for all the EU member states. The 
national programmatic documents developed under the EU directives and regulations foresee that in a realistic time frame the agricultural sector in Romania will function according to "the European agricultural model, characterized through viable holding structures, close to the market, simultaneous with rural development and environmental protection" (NSSD, 2008).

In order to implement the European type of agriculture in Romania is necessary to carefully assess and monitor the activities of agricultural holdings across the country and to conduct comparative analyses. For Romanian agriculture, the reference point for comparisons is the type of European farm that functions on principles of efficiency and competitiveness and seeks balance between human activities and preserving the environment.

Farms include various production factors in their activity, and their management manner, as well as the applied policies, generates a certain financial-patrimony situation. The analysis of the main correlations established between various elements of the patrimonial situation highlights the existence and size of the economic-financial potential of the farm, meaning the existence of a qualitative method for converting internal resources into an efficient and effective production activity.

Because accounting data about EU farms are structured within the FADN according to the financial accounting system, a series of methods used in the financial analysis of companies may be utilized to diagnose the management manner of agricultural holdings in various regions of Europe. One of the opportunities to assess the patrimonial potential of holdings is based on patrimonial structure rates determined for assets, as well as for liabilities (Vintilă, 2006).

The rates of patrimonial structure allow identifying the action of various factors over the economic and financial activity of farms, found in a certain structure of the patrimonial elements. The correlations established between assets or liabilities and total patrimony express the intensity and rationality of agricultural practices applied for a personalized technical and organizational structure, of adopted strategies and policies, of relationships with external partners, of economic, political and legal frameworks, etc.

If the patrimony of farms is studied in dynamic, we may assess how the patrimony evolves from one period to the next with the help of the structure rates. By making comparisons with another entity, we can highlight the elements that characterize the holding compare with the benchmark and the necessary measures to improve the economic and financial situation.

The general calculus relation for the rates of the assets $(R A)$ or liabilities $(R L)$ structure is:

$$
R A / R L=\frac{E A / E L}{T P}
$$

where: $E A$ and $E L$ represent the patrimony element / group of assets or liabilities $T P$ - total patrimony.

The main structure rates for the analysis of the farm's assets are:

- the fixed assets rate that is detailed by type of fixed assets:

$$
\frac{\text { Fixed assets }}{\text { Total patrimony }}
$$

$$
\begin{aligned}
& \frac{\text { Non-breeding livestock }}{\text { Total patrimony }} ; \frac{\text { Stock of agricultural products }}{\text { Total patrimony }} ; \\
& \frac{\text { Machinery }}{\text { Total patrimony }} ; \frac{\text { Breeding livestock }}{\text { Total patrimony }}
\end{aligned}
$$


- rate of current assets detailed by types of current assets:

$$
\begin{gathered}
\frac{\text { Current assets }}{\text { Total patrimony }} \\
\frac{\text { Land permanent crops }}{\text { Total patrimony }} ; \frac{\text { Buildings }}{\text { Total patrimony }} ; \frac{\text { Other circulating capital }}{\text { Total patrimony }}
\end{gathered}
$$

- rate of financial stability that reflects the role of the farm's permanent capital in conducting the activity:

$$
\frac{\text { Long \& medium term loans }+ \text { Net worth }}{\text { Total patrimony }}
$$

- the financial autonomy rate reflects the extent to which the farm finances its activity from equity capitals (or net worth) and its solvency level. Another formula provides information regarding the weight of equity capitals within stable funding resources:

$$
\frac{\text { Net worth }}{\text { Total patrimony }} ; \quad \frac{\text { Net worth }}{\text { Long \& medium term loans }+ \text { Net worth }}
$$

- the financial security rate expresses the structure of the financing sources:

$$
\frac{\text { Net worth }}{\text { Long \& medium term loans }}
$$

- the farm's indebtedness rate:

$$
\frac{\text { Liabilities }}{\text { Total patrimony }}
$$

Data regarding the main economic-financial indicators that characterize the patrimony of an agricultural holding (act as average indicators) were collected for the year 2007 in order to identify structural differences between Romanian farms and farms in the European Union. The data are organized according to the concept of the patrimonial balance sheet for agricultural holdings and are presented in table 1 . 
Table no. 1

Patrimony assets and liabilities for Romanian and EU agricultural holdings, 2007

\begin{tabular}{|l|c|c|c|}
\hline \multicolumn{1}{|c|}{$\begin{array}{c}\text { Indicators } \\
\text { (Euro) }\end{array}$} & EU & Romania & EU/Romania \\
\hline 1. Total assets & 275873 & 28432 & 9.7 \\
\hline Total fixed assets & 220668 & 21704 & 10.2 \\
\hline - Land permanent crops \& quotas & 148546 & 6254 & 23.8 \\
\hline - Buildings & 35839 & 8383 & 4.3 \\
\hline - Machinery & 26769 & 5555 & 4.8 \\
\hline - Breeding livestock & 9515 & 1511 & 6.3 \\
\hline Total current assets & 55204 & 6729 & 8.2 \\
\hline - Non-breeding livestock & 7375 & 977 & 7.5 \\
\hline - Stock of agricultural products & 7516 & 798 & 9.4 \\
\hline - Other circulating capital & 40313 & 4954 & 8.1 \\
\hline 2. Total liabilities & 39118 & 1069 & 36.6 \\
\hline - Long \& medium-term loans & 29307 & 658 & 44.5 \\
\hline - Short-term loans & 9811 & 411 & 23.9 \\
\hline 3. Net worth & 236754 & 27364 & 8.7 \\
\hline
\end{tabular}

Source: EU FADN Database - Balance sheet\&Assets; Balance sheet\&Liabilities

The main structure rates of a farm's patrimony determined for the European Union and for Romania (average farms) are presented in table 2.

Table no. 2

Patrimony structure coefficients for farms in Romania and the EU, 2007
\begin{tabular}{|l|c|c|}
\hline Patrimonial structure coefficients (\%) & EU & Romania \\
\hline 1. Rate of total fixed assets: & & \\
\hline - Land permanent crops \& quotas & 79.99 & 76.33 \\
\hline - Buildings & 53.84 & 22.00 \\
\hline - Machinery & 12.99 & 29.48 \\
\hline - Breeding livestock & 9.7 & 19.54 \\
\hline 2. Rate of total current assets & 3.45 & 5.31 \\
\hline - Non-breeding livestock & 20.01 & 23.67 \\
\hline - Stock of agricultural products & 2.67 & 3.44 \\
\hline - Other circulating capital & 2.72 & 2.81 \\
\hline 3. Financial stability coefficient & 14.61 & 17.42 \\
\hline 4. Rate of financial autonomy & 96.44 & 98.87 \\
\hline 5. Rate of financial security & 85.82 & 96.24 \\
\hline 6. Indebtedness rate: & 807.84 & 4158.66 \\
\hline - Long \& medium-tem loans & 14.18 & 3.76 \\
\hline - Short-term loans & 10.62 & 2.31 \\
\hline
\end{tabular}

Source: calculated data

The comparative analysis of farm's patrimony in Romania and the EU apparently doesn't highlight the existence of major differences regarding the correlations between patrimonial elements characteristic to the agricultural micro-economy in the EU and Romania at the time of its accession to the European agricultural system. These two types of farms function with an almost identical structure of the patrimonial elements, where approximately two thirds represent the share 
of fixed assets and one third is the share of current assets. Having contracted very small loans, agricultural holdings in Romania have an indebtedness coefficient that is three times lower than in the European Union and have high autonomy and financial stability. Studying the patrimonial structure coefficients on types of fixed assets reveals qualitative differences. Therefore, the share of lands in total patrimony in Romanian farms is 2.4 times lower than the European average, but assets like buildings and machinery have a double share.

If we consider the size ratio between the same type of patrimonial elements in the EU and Romania, we notice a much different situation in which the differences of productive potential are obvious (table 1). An average sized farm in Romania manages a 9.7 smaller patrimony than the one of a European farm, its production capacity being therefore much diminished. The technical productive base is ten times smaller and the value of the current assets used in agricultural activities is over eight times lower compared to the EU average. The biggest differences between the assets of the analyzed farms are found in the category of Land permanent crops \& quotas (23.8 times). This situation suggests that Romania practices agriculture on very small areas of land and the price of the agricultural land is much lower compared to the EU average. The data presented by Eurostat highlight the particular situation of Romania, who holds the first place among the EU member state regarding the number of farms with an agricultural area below 5 hectares (3530720) and only 14400 farms with a agricultural area exceeding 50 hectares ( $0.4 \%$ of total).

At the same time, Romanian farms have an important deficit regarding financing sources, the ratio between EU and Romania in terms of operations based on loans being 36.6 to 1 .

A complex characterization of the agricultural systems' viability requires the rounding of the analysis of the patrimonial structure with the study of indicators that reflect the balanced functioning of farms, as well as the analysis regarding their capacity to be efficient (Dănulețiu, 2009).

\section{Performance analysis for Romanian farms}

The economic performance of farms is the fundamental element upon which their viability depends in the context of the competitive environment provided by the market economy.

A clear picture regarding the performance recorded at the level of agricultural holdings may be obtained from the analysis of assets, management and work performances (Batteles, 2000). These may be expressed through efficiency indicators determined in accordance to the size of the made efforts and obtained results. The effort indicators represent various production factors involved in the activity, such as assets, productive capital, equity capitals, work, investments, and the result indicators may be expressed by Total Output, Farm Net Value Added, Farm Net Income.

In a farm, the analysis of the economic-financial performance may use the indicators: work productivity and rates of return. The most common rates that combine the result of a company with the made investments are Return on farm assets (ROFA) and Return on farm equity (ROFE) (Alexander et al., 2006).

$R O F A$, an important indicator of profitability, shows the ability of the farm's assets to generate income. It also shows the intensity of the farm's capital, so a low ROFA may suggest large investments or the use of high value stocks. From the investor's point of view, it is desirable to have a ROFA as high as possible. This proves the existence of an efficient management that generates high incomes by administrating a small and reasonably allotted capital. The situation may also have a fictional feature, the high return being owed to the existence of old and depreciated fixed assets (Rotan, 2001). The calculus formula is:

$$
\text { ROFA }=\frac{\text { Farm Net Income }}{\text { Total assets }}
$$


We can analyze the efficiency of using equity capitals within the farm by determining Return on farm equity (ROFE). If the farm obtains a high level of $R O F E$, it is an indication regarding the existence of an efficient management of equity capitals. A too high rate may mean a farm with low equity capitals.

$$
\text { ROFE }=\frac{\text { Farm Net Income }}{\text { Net worth }}
$$

In order to conduct the performance analysis regarding the use of the patrimony of farms in Romania compared to farms in the European Union, we used data about the obtained results, investments and efficiency (table 3).

Table no.3

Farm performance in Romania and the EU, 2007

\begin{tabular}{|l|c|c|c|}
\hline \multicolumn{1}{|c|}{ Indicators } & EU & Romania & $\begin{array}{c}\text { EU/Romani } \\
\mathbf{a}\end{array}$ \\
\hline 1. Average farm capital, euro & 131300 & 22492 & 5.8 \\
\hline 2. Gross investment, euro & 8414 & 480 & 17.5 \\
\hline 3. Net investment, euro & 820 & -598 & - \\
\hline 4.Labour input, hours & 3701 & 4872 & 0.76 \\
\hline 5. Total output, euro & 60287 & 10470 & 5.8 \\
\hline 6. Farm Net Income, euro & 19541 & 3151 & 6.2 \\
\hline 7. Farm Net Value Added, euro & 28546 & 4826 & 5.9 \\
\hline 8. Farm Net Income/FWU, euro & 14779 & 1730 & 8.5 \\
\hline 9. Farm Net Value Added/AWU, & & & 7.2 \\
euro & 16651 & 2328 & \\
\hline 10. Return on farm assets, \% (ROFA) & 7.09 & 11.08 & 0.64 \\
\hline 10.1. Return on fixed assets: & 8.8 & 14.5 & 0.61 \\
\hline 10.2. Return on current assets: & 35.4 & 46.8 & 0.76 \\
\hline 11. Return on farm equity, \% (ROFE) & 8.2 & 11.5 & 0.71 \\
\hline
\end{tabular}

Source: EU FADN Database - Income statement, Financial statement

The analysis of the main performance indicators for Romanian agricultural holdings highlights a contradictory situation. The differences regarding the main effort indicators are big. An agricultural holding has a 5.8 times lower Average farm capital than the capital used by farms in the European Union, and the investments are very low and are mostly based on amounts recovered from depreciation. The gross investments level is 17.5 times lower than in the EU, which doesn't ensure the increase of the operating capital and limits future opportunities to reach the production potential of European agriculture. The working hours in the production activity are $24 \%$ longer and the obtained incomes are low (5.8 times lower than in the EU). Having a net profit and a Net Value Added approximately 6 times lower than the European Union, Romanian farms also have low workforce productivity. Therefore, the productivity of employees in farms is 8.5 times lower and the annual work unit productivity is 7 times lower than in the EU.

Return on farm assets in Romania is approximately $4 \%$ higher than in the European Union and the return on equity is $3.2 \%$ higher, which suggest positive aspects regarding performance, but which must be carefully interpreted. In reality, higher return on patrimonial elements is not a result of better resources and capital management, but is due to a low volume of conducted agricultural activities, where the involved production factors have extremely low values. 


\section{Conclusions}

The information provided by FADN allows an assessment of the financial position and economic performance of farms in the European Union. In the context of the competitive environment, favoured by the Common Agricultural Policy, the mentioned aspect is useful in underlying economic policies that regard the agricultural sector at macroeconomic level, as well as decisions regarding the allotment and use of resources at microeconomic level.

The conducted analysis highlighted a few of the defining aspects of Romanian farms. Among EU member state, they hold a relatively modest position, being defined by a reduced production potential. The agriculture practiced in the productive systems in Romania takes place on a small scale, one of the causes being the small and dispersed lands owned by farms. The insufficient financing sources limit the adoption of active investment strategies that could form the basis for developing their technical and productive capacity. At the same time, the situation reflects the existence of an unstimulating internal crediting environment, as well as a neglect of the development opportunities provided by including farms into the financing systems of the European Union.

The viability of agricultural holdings is largely linked to the existence and efficient management of the full set of financial resources intended to potentiate superior economic results and increased performance. In addition to the need of earning enough revenues from their own activity, it's necessary to involve in the financing system other sources, such as crediting resources and money received from European funds.

The differences noticed at microeconomic level in terms of the agricultural organizational and productive structures show the gap between Romanian agriculture and the agriculture practiced in developed EU countries. To mitigate the differences in development quality is necessary to restructure the technical, productive and organizational systems in agriculture. In a reasonable amount of time, these must become real viable and efficient production centres, with positive impact on the life of rural communities and on the environment, so that their operation will fit into the European vision of sustainable development.

\section{References}

1. Alexander D., Britton A., Jorissen A., 2006. International Financial Reporting and Analysis, Thompson Learning.

2. Battles R., Thompson R. C., 2000. Fundamentals of agribusiness finance, Iowa State University Press.

3. Bergschmidt A., Dirksmeyer W., 2006. A Comparison of Farm Investment Support in Selected EU Member States, Working Papers in Agricultural Economics, no. 03.

4. Burja C., Burja V., 2008. The Economic Performance of Agricultural Holdings in the System of Sustainable Development, Casa Cărții de Ştiință Publishing, Cluj-Napoca.

5. Burja C., Burja V., 2010. Sustainable Value analysis for Romanian agriculture, Environmental Engineering and Management Journal, vol.9, no. 6, 839-846.

6. Cardwell M., 2004. The European model of agriculture, Oxford University Press, UK.

7. Csajbok I., 2009. Analysis of the accounting system of the Farm Accountancy Data Network, 4th Aspects and Visions of Applied Economics and Informatics, Debrecen, Hungary, pp. 648-652.

8. Dănulețiu A.E., 2009. Financial Stability Analysis for Company, Aeternitas Publishing House, Alba Iulia.

9. Deaconu S-C., 2009. Policies, Options and Accounting Treatments regarding Agricultural Holdings, Casa Cărții de Ştiință Publishing, Cluj-Napoca.

10. Eurostat database, available at http://epp.eurostat.ec.europa.eu. 
11. Feleagă N., 2006. Accounting in Romania at the Convergence Time with European Directives and International Referential, Theoretical and Applied Economics, issue 4(499) (supplement), pp. 89-114.

12. Juvancic L., Erjavec E., 2005. Intertemporal analysis of employment decisions on agricultural holdings in Slovenia, Agricultural Economics, volume 33, issue 2, pages 153161.

13. NSSD National strategy for sustainable development, Romania 2013-2020-2030, 2008. Ministry of Environment and Sustainable Development, Bucharest, Romania.

14. Rotan B. L., 2001. Analysis of Financial Statments: Local Farm Supply, Marketing Cooperatives, USDA RBS Research Report 182, Washington.

15. Schroder S., Begemann F., Harrer S., 2007. Agrobiodiversity monitoring - documentation at European level, Journal für Verbraucherschutz und Lebensmittelsicherheit, volume 2, supplement 1, 29-32.

16. Vintilă G., 2006. Financial Management of Companies, Didactică şi pedagogică Publishing House, Bucharest

17. Vrolijk H.C.J., Bont C.J.A.M., Blokland P.W., Soboh R.A.M.E., 2010. Farm Viability in the European Union, Assessement of the impact of changes in farm payements, LEI Reports 2010-011, The Hague. 